\title{
SISTEM DINAMIS KETERSEDIAAN DAGING SAPI DI PROVINSI BALI
}

\author{
Ni Made Evi Yulastari, I Ketut Satriawan*, Cokorda Anom Bayu Sadyasmara \\ PS Teknologi Industri Pertanian, Fakultas Teknologi Pertanian, Universitas Udayana, Kampus Bukit \\ Jimbaran, Badung, Kode pos : 80361; Telp/Fax : (0361) 701801.
}

Diterima 14 September 2018 / Disetujui 02 November 2018

\begin{abstract}
The demand for beef in Bali Province is very high and dominated with hotels, restaurants, and cafes. The purpose of this research is to know the factors that influence the availability of beef, analyze the availability of beef, and make alternative policy recommendation that can be done in order to meet the demand of beef. This research was conducted in Bali Province using system dynamic approach. Simulation are conducted over a period of 10 year, starting from 2012 until 2021. Factors affecting beef availability is beef production and beef demand. Simulation results show that beef production in Bali Province has not been able to meet the demand of beef. The availability of beef in Bali Province tended to decline from the beginning of the simulation year to the end of the simulation year. Based on the simulation results of several scenarios, the most effective and possibly developed policy to meet the needs of beef is through the efforts of fattening cattle.
\end{abstract}

Key words: dynamic system, availability, beef, simulations,

\begin{abstract}
ABSTRAK
Kebutuhan daging sapi di Provinsi Bali sangat tinggi dan lebih didominasi untuk memenuhi kebutuhan hotel, restoran, dan cafe. Tujuan penelitian adalah untuk mengetahui faktor-faktor yang mempengaruhi ketersediaan daging sapi, menganalisis ketersediaan daging sapi, dan membuat alternatif rekomendasi kebijakan yang dapat dilakukan dalam rangka memenuhi kebutuhan daging sapi. Penelitian ini dilakukan di Provinsi Bali dengan menggunakan pendekatan sistem dinamis. Simulasi dilakukan selama kurun waktu 10 tahun, mulai dari tahun 2012 sampai tahun 2021. Faktor-faktor yang mempengaruhi ketersediaan daging sapi adalah produksi daging sapi dan kebutuhan daging sapi. Hasil simulasi menunjukkan bahwa produksi daging sapi di Provinsi Bali belum mampu memenuhi kebutuhan daging sapi. Ketersediaan daging sapi di Provinsi Bali cenderung mengalami penurunan mulai tahun awal simulasi sampai akhir tahun simulasi. Berdasarkan hasil simulasi beberapa skenario, kebijakan yang paling efektif dan mungkin dikembangkan untuk memenuhi kebutuhan daging sapi adalah melalui upaya penggemukan sapi.
\end{abstract}

Kata kunci : sistem dinamis, ketersediaan, daging sapi, simulasi.

*Korespondensi Penulis:

Email: satriawan@unud.ac.id 


\section{PENDAHULUAN}

Daging merupakan bahan pangan yang penting untuk memenuhi kebutuhan protein hewani.Kebutuhan konsumsi daging khususnya sapi di Indonesia terus meningkat. Peningkatan konsumsi daging sapi dari tahun 2012 - 2016 sebesar 3,21\%. Peningkatan jumlah penduduk dan kesadaran masyarakat akan pentingnya protein hewani berpengaruh terhadap peningkatan kebutuhan daging sapi. Permintaan daging sapi yang terus meningkat tidak diimbangi oleh peningkatan produksi daging sapi dalam negeri. Ketersediaan daging sapi nasional masih mengalami kekurangan, yang ditutupi melalui impor sekitar 35\% dari total kebutuhan daging sapi nasional (Ditjennak, 2010). Produksi daging sapi mengalami peningkatan sebanyak 24.437 ton dari tahun 2010 - 2015. Pencapaian produksi daging sapi terbesar di Indonesia pada tahun 2015 ada pada Provinsi Jawa Timur yaitu sebesar 261.999 ton dari total produksi Indonesia pada tahun 2015 sebesar 1.207.170 ton (BPS, 2016).Populasi sapi di Bali pada tahun 2016 sebanyak 546.370 ekor sapi. Sapi dihasilkan dari seluruh Kabupaten di Provinsi Bali. Kabupaten yang memiliki populasi sapi terbanyak selama tahun 2016 adalah Kabupaten Buleleng dengan populasi sapi sebanyak 125.439 ekor (Disnakkeswan, 2016).

Simulasi merupakan metode untuk mempelajari macam - macam model sistem di dunia nyata secara luas dengan evaluasi numerik menggunakan softwere yang didesain untuk meniru karakteristik atau operasi tertentu dari sistem (Kelton et al., 2010).Simulasi terbukti sebagai alat evaluasi performansi yang efektif dan alat pemodelan untuk sistem stokastik di dunia nyata yang sangat kompleks.Pendekatan simulasi yang banyak digunakan adalah sistem dinamis.

Sistem dinamis merupakan kerangka yang memfokuskan pada sistem berpikir dengan carafeed back loop dan mengambil beberapa langkah tambahan struktur serta mengujinya melalui model simulasi komputer (Forrester, 1994).Salah satu pendekatan simulasi yang banyak dipakai adalah dengan sistem dinamis. Pendekatan sistem dinamis telah digunakan mensimulasikan ketersediaan daging sapi nasional (Harmini et al.,2011), analisis produksi kedelai dan permintaan untuk mengembangkan kebijakan strategis swasembada pangan (Hasan et al.,2015),ketersediaan beras di Jawa Timur (Garside dan Asjari, 2015, pola divestasiagroindustriberas (Udin et al., 2014), swasembada kedelai di Provinsi Bali (Krisdayanti et al., 2017) dan ketersediaan pisang di Provinsi Bali (Indayani et al., 2017).

Berdasarkan kemampuan simulasi dalam menirukan perilaku sistem yang dapat memprediksi kondisi mendatang maka penelitian lebih lanjut mengenai sistem dinamis ketersediaan daging sapi dilakukan di Provinsi Bali.Penelitian ini bertujuan untuk(1) menentukan faktor-faktor yang mempengaruhi ketersediaan daging sapi, (2) menghitung ketersediaan daging sapi, (3) menyusun pemodelan dinamis sistem ketersediaan daging sapi, dan (4) membuat alternatif rekomendasi kebijakan untuk memenuhi kebutuhan daging sapi di Provinsi Bali.

\section{METODE PENELITIAN}

\section{Waktu dan Lokasi Penelitian}

Penelitian ini dilaksanakan pada Juni sampai Juli 2017 di Provinsi Bali dengan objek penelitian daging sapi.Pemilihan lokasi dilakukan secara sengaja (purposive) dengan mempertimbangkan bahwa Bali sebagai tujuan wisata dunia yang memiliki daya tarik tersendiri.

\section{Tahapan Penelitian}

Tahapan yang dilakukan dalam penelitian 
sesuai dengan metodelogi pengembangan model sistem dinamis yaitu, (1) Identifikasi masalah dan tujuan, (2) konseptualisasi model, (3) formulasi model, (4) verifikasi dan validasi model, (5) simulasi dengan scenario dan (6) penyusunan alternatif rekomendasi skenario kebijakan.

\section{HASIL DAN PEMBAHASAN}

\section{Gambaran Umum Daging Sapi di Provinsi Bali}

Ternak memiliki arti penting dalam aspek pangan dan ekonomi masyarakat. Daging sapi dalam aspek pangan ditujukan untuk pemenuhan kebutuhan protein hewani. Populasi sapi di Bali pada tahun 2016 sebanyak 546.370 ekor sapi. Kebutuhan daging sapi di Bali masih didominsi dari impor daging sapi. Daging sapi juga digunakan utuk memenuhi kebutuhan hotel, restoran, cafe (HORECA), kebutuhan hari raya (idul fitri, idul adha, natal), kebutuhan langsung dan kebutuhan industri olahan. Perkembangan produksi daging di Bali saat ini belum bisa memenuhi semua kebutuhan daging sapi di Bali, hal ini terbukti karena masih adanya impor daging sapi yang masih mendominasi.

\section{Rancangan Model Ketersediaan Daging Sapi di Provinsi Bali}

1. Deskripsi Sistem

Daging sapi merupakan suatu permasalahan ketersediaan yang kompleks yang melibatkan variabel yang saling berkaitan. Ketersediaan daging sapi dipantau untuk memenuhi kebutuhan HORECA (hotel, restoran cafe) dan kebutuhan pangan masyarakat khususnya di Provinsi Bali. Sistem ketersediaan daging sapi dibuat dalam model simulasi yang sesuai dengan model permasalahan di lapangan sebagai arah kebijakan dalam pengambilan keputusan. Model sistem dinamis yang dikembangkan dibatasi pada hal-hal yang berkaitan dengan produksi serta kebutuhan daging sapi di Provinsi Bali. Ketersediaan daging sapi dibagi menjadi dua submodel yaitu submodel produksi dan kebutuhan untuk mempermudah dalam pemodelan. Pemodelan simulasi ketersediaan daging sapi di Provinsi Bali dituangkan kedalam bentuk matematis dengan menggunakan software Vensim PLE.

2. Konseptualisasi Model

Model konseptual interaksi antara submodel utama dengan model lainnya disajikan pada Gambar 1.

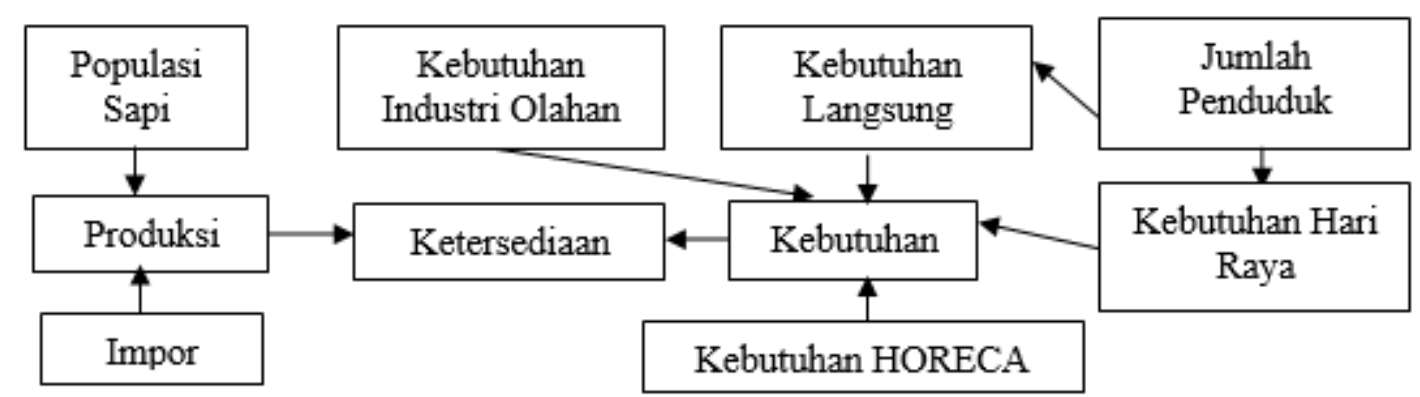

Gambar 1. Model Konseptual Ketersediaan Daging Sapi

Model konseptual ketersediaan daging sapi diatas memiliki hubungan yang saling mempengaruhi. Model yang dibuat merupakan replikasi dari sistem nyata yang memiliki dua submodel yaitu submodel produksi daging sapi dan submodel kebutuhan daging sapi. Ketersediaan daging sapi dipengaruhi oleh submodel produksi daging sapi yang mencangkup populasi sapi, impor daging sapi dan submodel kebutuhan daging sapiyang mencangkup kebutuhan industri olahan, kebutuhan HORECA, 
kebutuhan hari raya dan kebutuhan langsung. Jumlah penduduk berpengaruh pada tingkat kebutuhan langsung dan kebutuhan hari raya.Submodel produksi daging sapi merupakan submodel yang menghasilkan daging sapi. Produksi daging sapi yang dimaksud adalah jumlah daging sapi yang diproduksi di Provinsi Bali dengan satuan (ton/tahun). Submodel kebutuhan daging sapi merupakan submodel yang dapat mengurangi persediaan daging sapi. Kebutuhan daging sapi yang dimaksud adalah jumlah daging sapi yang digunakan untuk memenuhi beberapa kebutuhan daging sapi di Provinsi Bali dengan satuan (ton/tahun).

\section{Formulasi Model}

Penyusunan stock and flow diagrammerupakan formulasi model yang disimulasikan setelah dilakukan formulasi matematis. Penyusunan stock and flow diagramsistem dinamis ketersediaan daging sapi di Provinsi Bali memiliki beberapa submodel yang mewakili subsistem produksi dan subsistem kebutuhan.Formulasi model dalam software Vensim ditunjukkan pada Gambar 2.

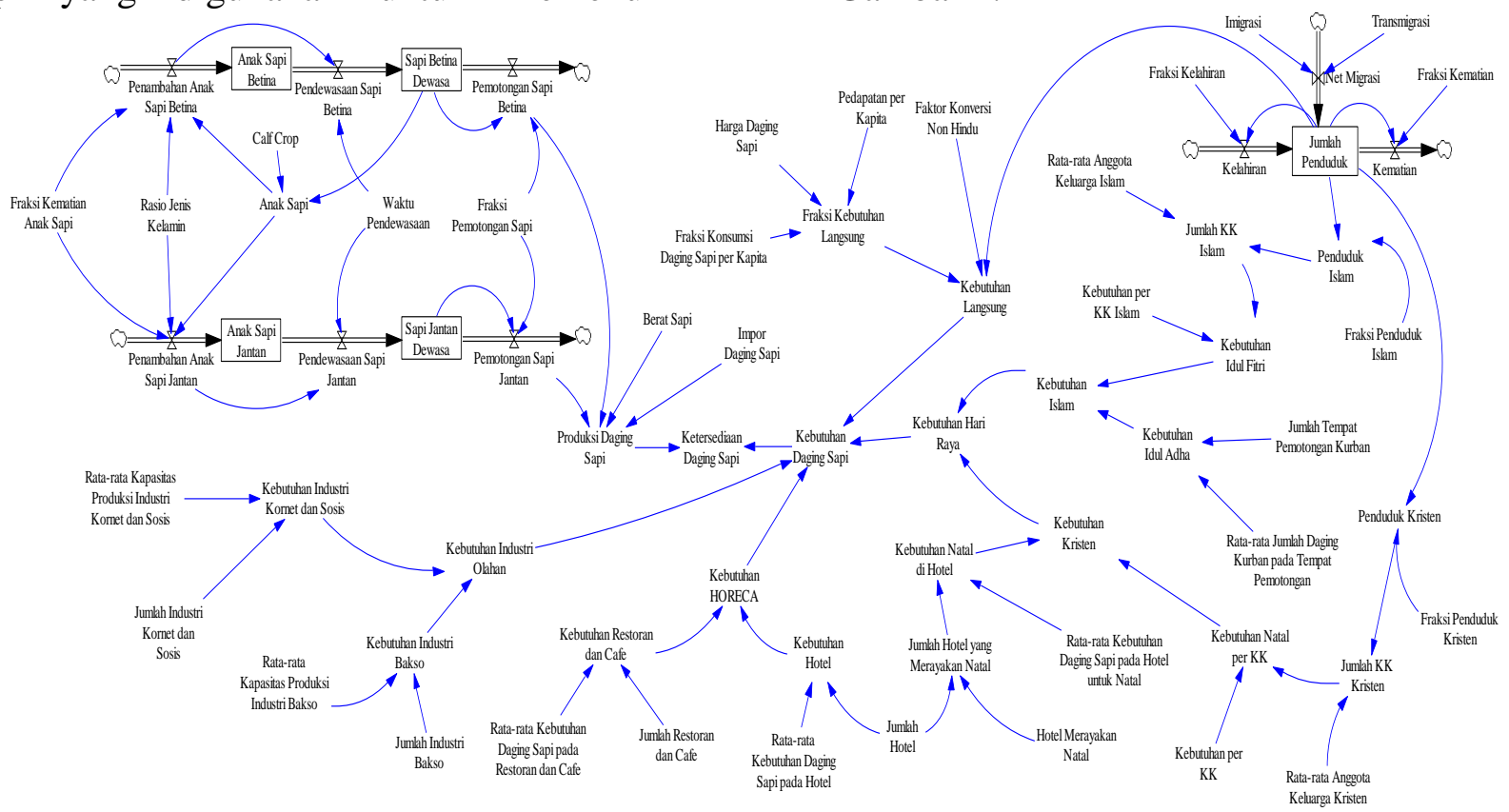

Gambar 2.Formulasi Model Sistem Dinamis Ketersediaan Daging Sapi.

\section{Verifikasi dan Validasi Model}

Verifikasi model merupakan tahapan yang dilakukan untuk memastikan model yang telah dibuat apakah sudah sesuai dengan konsep secara tepat atau tidak antara model dengan kondisi nyata. Vensim (Ventana Simulation) merupakan software yang digunakan dalam proses verifikasi, ketika model tidak menyatakan pesan error maka model tersebut telah verified (bebas error). Verifikasi ketersediaan daging sapi di Provinsi Bali yang menyatakan "Unit are OK" artinya model sudah terverifikasi. Rekapitulasi $P$ value atau nilai signifikansi 2 tailed dari seluruh uji statistik atau hasil validasi model simulasi dengan menggunakan Microsoft Excel ditunjukkan pada Tabel 1.

Berdasarkan uji statistik yang dilakukan, nilai $P$ value untuk produksi daging sapi mengasilkan $P$ value 0,264, pemotongan sapi 0,188 , jumlah anak sapi betina 0,051 , jumlah anak sapi jantan 0,064 , jumlah sapi betina 0,067 , jumlah sapi jantan 0,464 dan jumlah penduduk 0,051 yang artinya $P$ value lebih besar dari 0,05 . $P$ value $\geq \alpha$ maka $\mathrm{H}_{0}$ diterima, artinya tidak ada perbedaan yang signifikan antara output nyata dan output simulasi. 
Model ketersedian daging sapi di Provinsi

Bali sudah dinyatakan valid.

Tabel 1.Hasil Validasi Menggunakan t-paired test.

\begin{tabular}{|c|c|c|c|c|c|c|}
\hline Variabel & Tahun & Hasil aktual & Data simulasi & $\begin{array}{l}\mathrm{P} \\
\text { value }\end{array}$ & Nilai a & Kesimpulan \\
\hline $\begin{array}{l}\text { Produksi } \\
\text { Daging Sapi } \\
\text { (ton/tahun) }\end{array}$ & $\begin{array}{l}2012 \\
2013 \\
2014 \\
2015 \\
2016 \\
\end{array}$ & $\begin{array}{l}12.792,20 \\
11.370,84 \\
9.126,85 \\
8.051,51 \\
9.654,58 \\
\end{array}$ & $\begin{array}{l}14.191,00 \\
12.197,50 \\
10.602,70 \\
9.326,85 \\
8.224,08 \\
\end{array}$ & 0,264 & 0,05 & $\mathrm{H}_{0}$ diterima \\
\hline $\begin{array}{l}\text { Jumlah } \\
\text { Pemotongan } \\
\text { Sapi (ekor) }\end{array}$ & $\begin{array}{l}2012 \\
2013 \\
2014 \\
2015 \\
2016\end{array}$ & $\begin{array}{l}51.643 \\
44.694 \\
36.231 \\
36.526 \\
36.431\end{array}$ & $\begin{array}{l}61.735,40 \\
51.767,90 \\
43.793,90 \\
37.414,70 \\
31.901,00\end{array}$ & 0,242 & 0,05 & $\mathrm{H}_{0}$ diterima \\
\hline $\begin{array}{lr}\text { Jumlah } & \text { Anak } \\
\text { Sapi } & \text { Betina } \\
\text { (ekor) } & \end{array}$ & $\begin{array}{l}2012 \\
2013 \\
2014 \\
2015 \\
2016\end{array}$ & $\begin{array}{l}80.100 \\
45.243 \\
63.138 \\
63.105 \\
63.367\end{array}$ & $\begin{array}{l}80.100,00 \\
80.100,00 \\
79.073,80 \\
77.226,60 \\
75.748,90\end{array}$ & 0,051 & 0,05 & $\mathrm{H}_{0}$ diterima \\
\hline $\begin{array}{lr}\text { Jumlah } & \text { Anak } \\
\text { Sapi } & \text { Jantan } \\
\text { (ekor) } & \end{array}$ & $\begin{array}{l}2012 \\
2013 \\
2014 \\
2015 \\
2016 \\
\end{array}$ & $\begin{array}{l}75.051 \\
47.433 \\
62.315 \\
61.128 \\
63.420 \\
\end{array}$ & $\begin{array}{l}75.051,00 \\
75.051,00 \\
74.024,80 \\
72.177,60 \\
70.699,90\end{array}$ & 0,064 & 0,05 & $\mathrm{H}_{0}$ diterima \\
\hline $\begin{array}{l}\text { Jumlah Sapi } \\
\text { Betina (ekor) }\end{array}$ & $\begin{array}{l}2012 \\
2013 \\
2014 \\
2015 \\
2016\end{array}$ & $\begin{array}{l}216.327 \\
187.684 \\
194.371 \\
189.818 \\
191.765\end{array}$ & $\begin{array}{l}216.327 \\
182.505 \\
154.815 \\
132.143 \\
112.739\end{array}$ & 0,067 & 0,05 & $\mathrm{H}_{0}$ diterima \\
\hline $\begin{array}{l}\text { Jumlah Sapi } \\
\text { Jantan (ekor) }\end{array}$ & $\begin{array}{l}2012 \\
2013 \\
2014 \\
2015 \\
2016\end{array}$ & $\begin{array}{l}92.350 \\
63.471 \\
76.147 \\
76.519 \\
76.144\end{array}$ & $\begin{array}{l}92.350,00 \\
81.001,60 \\
71.710,40 \\
64.103,40 \\
57032,3\end{array}$ & 0,464 & 0,05 & $\mathrm{H}_{0}$ diterima \\
\hline $\begin{array}{l}\text { Jumlah } \\
\text { Penduduk }\end{array}$ & $\begin{array}{l}2012 \\
2013 \\
2014 \\
2015 \\
2016\end{array}$ & $\begin{array}{l}4.007 .200 \\
4.056 .300 \\
4.104 .900 \\
4.152 .800 \\
4.200 .100\end{array}$ & $\begin{array}{l}4.007 .200 \\
4.082 .230 \\
4.158 .100 \\
4.234 .820 \\
4.312 .400\end{array}$ & 0,051 & 0,05 & $\mathrm{H}_{0}$ diterima \\
\hline
\end{tabular}

\section{Hasil Simulasi Berbagai Skenario}

Simulasi model dilakukan untuk mendapatkan hasil serta perilaku sistem selama periode simulasi 2012-2021.Dalam 
model dinamis ini dicobakan beberapa kebijakan melalui simulasi skenario untuk mencapai ketersediaan daging sapi. Pada model dinamis, skenario dilakukan dengan cara mengubah nilai variabel yang berkaitan sebagai implementasi dari suatu kebijakan yang ingin dilakukan.Simulasi sistem dengan skenario kebijakan akan menghasilkan berbagai skenario kebijakan dan implikasinya terhadap variabel output sistem.

1. Skenario Tanpa Perubahan Kebijakan (skenario 1)

Skenario tanpa perubahan kebijakan disimulasikan atas dasar kondisi yang telah berjalansekarang ini.Pada skenario ini dapat dilihat perubahan yang terjadi selama kurun waktu 10 tahun dari tahun 2012-2021.Hasil simulasi menunjukkan bahwa penurunan produksi daging sapi terjadi setiap tahunnya, hal ini disebabkan karena populasi sapi tiap tahun terus berkurang. Berkurangnya produksi daging sapi menyebabkan kebutuhan daging sapi tidak terpenuhi. Hasil simulasi skenario tanpa perubahan kebijakanmengenai jumlah penduduk,pemotongan sapi, produksi daging sapi, kebutuhan daging sapi, impor daging sapi dan ketersediaan daging sapi disajikan pada Tabel 2.

Hasil simulasi model kondisi pemotongan sapi selama periode tahun 2016-2021 cenderung mengalami penurunan yaitu dari $61.735,40$ ekor pada tahun 2016 menjadi 16.263,74 ekor pada tahun 2021.Hasil simulasi produksi daging sapi selama periode tahun 2012-2021 mengalami penurunan. Pada tahun 2012 produksi daging sapi sebesar 14.191,00 ton menjadi 5.096,65 ton pada tahun 2021, sedangkan hasil simulasi kebutuhan daging sapi setiap tahunnya mengalami peningkatan. Produksi daging sapi di Provinsi Bali yang mengalami penurunan mengakibatkan tidak bisa memenuhi kebutuhan daging sapi.

Tabel 2. Hasil Simulasi Skenario Tanpa Perubahan Kebijakan.

\begin{tabular}{|c|c|c|c|c|c|c|c|}
\hline \multirow[b]{2}{*}{ Tahun } & \multirow{2}{*}{$\begin{array}{l}\text { Jumlah } \\
\text { Penduduk } \\
\text { Bali }\end{array}$} & \multirow{2}{*}{$\begin{array}{l}\text { Pemotongan } \\
\text { Sapi (ekor) }\end{array}$} & \multirow{2}{*}{$\begin{array}{l}\text { Produksi } \\
\text { Daging Sapi } \\
\text { (Ton) }\end{array}$} & \multicolumn{2}{|c|}{ Kebutuhan } & \multicolumn{2}{|c|}{ Ketersediaan } \\
\hline & & & & $\begin{array}{l}\text { Daging } \\
\text { (Ton) }\end{array}$ & Sapi & $\begin{array}{l}\text { Daging } \\
\text { (Ton) }\end{array}$ & Sapi \\
\hline 2012 & 4.007 .200 & $61.735,40$ & $14.191,00$ & $21.369,9$ & & $-7.171,9$ & \\
\hline 2013 & 4.082 .230 & $52.701,00$ & $12.197,50$ & $21.388,2$ & & $-9.190,7$ & \\
\hline 2014 & 4.158 .100 & $45.305,00$ & $10.602,70$ & $21.406,8$ & & $-10.804,1$ & \\
\hline 2015 & 4.234 .820 & $39.249,40$ & $9.326,85$ & $21.425,5$ & & $-12.098,7$ & \\
\hline 2016 & 4.312 .400 & $33.954,30$ & $8.224,08$ & $21.444,5$ & & $-13.220,4$ & \\
\hline 2017 & 4.380 .840 & $29.342,80$ & $7.276,19$ & $21.463,7$ & & $-14.187,5$ & \\
\hline 2018 & 4.468 .400 & $25.341,34$ & $6.465,34$ & $21.483,1$ & & $-15.017,7$ & \\
\hline 2019 & 4.470 .170 & $21.871,71$ & $5.772,36$ & $21.502,7$ & & $-15.730,3$ & \\
\hline 2020 & 4.631 .500 & $18.865,72$ & $5.180,75$ & $21.522,5$ & & $-16.341,7$ & \\
\hline 2021 & 4.713 .520 & $16.263,74$ & $4.676,22$ & $21.542,5$ & & $-16.866,3$ & \\
\hline
\end{tabular}

2. Skenario Produksi (skenario 2)

Skenario produksi yaitu dimana skenario yang dirancang dengan mengasumsikan terjadi peningkatan produksi dengan cara peningkatan berat sapi yang akan dipotong. Berat sapi yang akan dipotong diasumsikan meningkat sebesar 50\% dari $200 \mathrm{~kg}$ menjadi $300 \mathrm{~kg}$. Peningkatan berat sapi dilakukan dengan cara memperhatikan pemberian pakan pada sapi. Hijauan yang dapat membantu mempercepat proses penggemukan adalah jenis hijauan unggul (rumput gajah, ilalang, benggala, setaria bede). Pakan tambahan (konsentrat) adalah dedak padi, ampas tahu, ampas singkong, vitamin, mineral, antibiotik dan ambolik (hormonal)(Taufiq dkk., 2017). Pakan sapi 
terdiri dari beberapa jenis yaitu hijauan dan pakan tambahan (konsentrat). Pakan yang diberikan pada sapi untuk dapat meningkatkan sapi sebesar $350 \mathrm{~g} /$ hari adalah dengan cara pemberian pakan tambahan sebanyak $7 \mathrm{~kg} / \mathrm{hari}$ dan pakan hijauan sebanyak $5 \mathrm{~kg} / \mathrm{hari}$ (Baskoro, 2009).Peningkatan bobot sapi belum bisa memenuhi kebutuhan daging sapi. Untuk memenuhi kebutuhan daging sapi diasumsikan terjadinya penambahan bibit sapi tiap tahunnya sebesar 40.000 ekor dan fraksi pemotongan ditingkatkan dari 0,2 fraction/year menjadi 0,3 fraction/year.
Penambahan bibit sapi diasumsikan dari ratarata penurunan sapi tiap tahunnya dan didasari dari daya tampung populasi sapi di Provinsi Bali adalah sebanyak 700.000 ekor. Peningkatan fraksi pemotongan sapi didasari oleh jumlah sapi yang dipotong di rumah potong hewan (RPH). Pemotongan sapi di $\mathrm{RPH}$ tiap tahun adalah 0.3 fraction/year. Hasil simulasi penambahan bibit dan peningkatan fraksi pemotongan sapi hanya dapat memenuhi kebutuhan daging sapi sampai tahun 2015. Hasil simulasi dapat dilihat pada Tabel 3.

Tabel 3. Hasil Simulasi Penambahan Bibit dan Peningkatan Fraksi Pemotongan.

\begin{tabular}{|c|c|c|c|c|c|}
\hline & Jumlah & & Produksi & Kebutuhan & Ketersediaan \\
\hline Tahun & $\begin{array}{l}\text { Penduduk } \\
\text { Bali }\end{array}$ & $\begin{array}{l}\text { Pemotongan } \\
\text { Sapi (ekor) }\end{array}$ & $\begin{array}{l}\text { Daging } \\
\text { (Ton)** }\end{array}$ & $\begin{array}{l}\text { Daging Sapi } \\
\text { (Ton) }\end{array}$ & $\begin{array}{l}\text { Daging } \\
\text { (Ton)** }\end{array}$ \\
\hline 2012 & 4.007 .200 & $61.735,40$ & $29.624,80$ & $21.369,9$ & $8.255,0$ \\
\hline 2013 & 4.082 .230 & $52.701,00$ & $25.961,40$ & $21.388,2$ & $4.573,2$ \\
\hline 2014 & 4.158 .100 & $45.305,00$ & $23.396,90$ & $21.406,8$ & $1.990,2$ \\
\hline 2015 & 4.234 .820 & $39.249,40$ & $21.601,90$ & $21.425,5$ & 176,3 \\
\hline 2016 & 4.312 .400 & $33.954,30$ & $20.251,50$ & $21.444,5$ & $-1.193,0$ \\
\hline 2017 & 4.380 .840 & $29.342,80$ & $19.240,60$ & $21.463,7$ & $-2.223,1$ \\
\hline 2018 & 4.468 .400 & $25.341,34$ & $18.487,00$ & $21.483,1$ & $-2.996,1$ \\
\hline 2019 & 4.470 .170 & $21.871,71$ & $17.924,70$ & $21.502,7$ & $-3.578,0$ \\
\hline 2020 & 4.631 .500 & $18.865,72$ & $17.505,00$ & $21.522,5$ & $-4.017,5$ \\
\hline 2021 & 4.713 .520 & $16.263,74$ & $17.191,60$ & $21.542,5$ & $-4.350,9$ \\
\hline
\end{tabular}

Keterangan **: nilai produksi dan ketersediaan daging sapi tiap tahun lebih tinggi dari hasil simulasi skenario 1.

\section{Skenario Pengaruh Peningkatan \\ Kebutuhan (skenario 3)}

Skenario ketiga yaitu pengaruh peningkatan kebutuhan, dimana model dirancang dengan mengasumsikan terjadinya perubahan pada kebutuhan daging sapi.Peningkatan kebutuhan daging sapi dipengaruhi oleh pertumbuhan penduduk dan wisatawan yang datang ke Bali. Pertumbuhun penduduk mempengaruhi peningkatan konsumsi langsung, hari raya dan industri olahan. Jumlah penduduk diasumsikan meningkat dengan cara menekan tingkat kematian. Fraksi kematian diasumsikan mengalami penurunan yaitu dari 0,0034 fraction/year dengan angka kematian kasar 3,4menjadi 0,0028 fraction/year dengan angka kematian kasar 2,7 berdasarkan data fraksi kematian Provinsi Bengkulu tahun 2012-2015 (diolah dari data Riskesdas 2007 dan BPS Provinsi Bengkulu, 2016).Penurunan fraksi kematian memungkinkan akan terjadi, mengingat bahwa angka fraksi kematian di Provinsi Balidari tahun 2012-2016 mengalami penurunan setiap tahunnya (BPS Provinsi Bali 2016). Jumlah wisatawan yang datang ke Bali mempengaruhi peningkatan kebutuhan HORECA. Rata-rata peningkatan pertumbuhan penduduk adalah $2 \%$ dan ratarata kunjungan wisatawan yang datang ke Bali adalah 12\% (BPS, 2016). Kebutuhan 
langsung, hari raya, HORECA dan industri olahan diasumsikan meningkat dengan cara menaikkan angka rata-rata kebutuhan daging sapi. Peningkatan kebutuhan disajikan pada Tabel 4.

Kenaikan kebutuhan daging sapi memungkinkan terjadi mengingat bahwa jumlah kunjungan wisatawan ke Bali dan pertumbuhan penduduk mengalami peningkatan setiap tahunnya. Perubahan peningkatan kebutuhan berakibat pada produksi daging sapi tidak dapat memenuhi kebutuhan daging sapi.Hasil simulasi skenario pengaruh peningkatan kebutuhandisajikan pada Tabel 5.

Tabel 4. Peningkatan Kebutuhan Daging Sapi

\begin{tabular}{llll}
\hline & $\begin{array}{l}\text { Persentase } \\
\text { Kenaikan }\end{array}$ & $\begin{array}{l}\text { Kebutuhan } \\
\text { Awal }\end{array}$ & $\begin{array}{l}\text { Kebutuhan } \\
\text { Naik }\end{array}$ \\
\hline $\begin{array}{l}\text { Kebutuhan Langsung } \\
\text { Konsumsi per kapita }\end{array}$ & $2 \%$ & 0,0017 & 0,001734 \\
\hline $\begin{array}{l}\text { Kebutuhan Hari Raya } \\
\text { Kebutuhan Islam }\end{array}$ & $2 \%$ & 0,0020 & 0,002040 \\
$\begin{array}{l}\text { Rata-rata Kurban } \\
\text { Kebutuhan Kristen }\end{array}$ & $2 \%$ & 45,8000 & 46,720000 \\
\hline Kebutuhan HORECA & $2 \%$ & 0,0012 & 0,001224 \\
$\begin{array}{l}\text { Rata-rata kebutuhan Hotel } \\
\text { Rata-rata kebutuhan RestoranCafe }\end{array}$ & $12 \%$ & & \\
Rata-rata kebutuhan Hotel untuk Natal & $12 \%$ & 5,2300 & 5,860000 \\
\hline $\begin{array}{l}\text { Kebutuhan Industri Olahan } \\
\text { Rata-rata kebutuhan bakso }\end{array}$ & $2 \%$ & 2,7500 & 3,080000 \\
Rata-rata kebutuhan kornet dan sosis & $2 \%$ & 0,2300 & 0,260000 \\
\hline
\end{tabular}

Tabel 5. Hasil Simulasi Skenario Pengaruh Peningkatan Kebutuhan.

\begin{tabular}{llllll}
\hline Tahun & $\begin{array}{l}\text { Jumlah } \\
\text { Penduduk } \\
\text { Bali** }\end{array}$ & $\begin{array}{l}\text { Pemotongan } \\
\text { Sapi (ekor) }\end{array}$ & $\begin{array}{l}\text { Produksi } \\
\text { Daging Sapi } \\
\text { (Ton) }\end{array}$ & $\begin{array}{l}\text { Kebutuhan } \\
\text { Daging Sapi } \\
\text { (Ton)** }\end{array}$ & $\begin{array}{l}\text { Ketersediaan } \\
\text { Daging Sapi } \\
\text { (Ton)** }\end{array}$ \\
\hline 2012 & 4.007 .200 & $61.735,40$ & $14.191,00$ & $22.418,7$ & $-8.227,7$ \\
2013 & 4.084 .520 & $52.701,00$ & $12.197,50$ & $22.438,0$ & $-10.240,5$ \\
2014 & 4.162 .760 & $45.305,00$ & $10.602,70$ & $22.457,6$ & $-11.854,9$ \\
2015 & 4.241 .910 & $39.249,40$ & $9.326,85$ & $22.477,4$ & $-13.150,6$ \\
2016 & 4.321 .990 & $33.954,30$ & $8.224,08$ & $22.497,5$ & $-14.273,4$ \\
2017 & 4.403 .020 & $29.342,80$ & $7.276,19$ & 22517.8 & $-15.241,6$ \\
2018 & 4.485 .010 & $25.341,34$ & $6.465,34$ & $22.538,3$ & $-16.073,0$ \\
2019 & 4.567 .950 & $21.871,71$ & $5.772,36$ & $22.559,0$ & $-16.786,6$ \\
2020 & 4.651 .880 & $18.865,72$ & $5.180,75$ & $22.580,1$ & $-17.399,4$ \\
2021 & 4.736 .790 & $16.263,74$ & $4.676,22$ & $22.601,3$ & $-17.925,1$ \\
\hline
\end{tabular}

Keterangan ** : nilai jumlah penduduk, kebutuhan daging sapi lebih tinggi dan ketersediaan daging sapi tiap tahun lebih rendah dari hasil simulasi skenario 1.

4. Skenario Peningkatan Produksi dan

Kebutuhan (skenario 4)

Skenario keempat merupakan skenario gabungan dari skenario 2 dan skenario 3 untuk melihat terpenuhi atau tidaknya kebutuhan daging sapi di Bali. Peningkatan produksi dan kebutuhan dapat dilihat pada Tabel 6. Produksi daging sapi tiap tahun mengalami penurunan sedangkan kebutuhan mengalami peningkatan tiap tahunnya yang 
mengakibatkan kebutuhan daging sapi hanya bisa terpenuhi sampai tahun 2014. Ketersediaan daging sapi masih mengalami kekurangan untuk memenuhi kebutuhan daging sapi di Provinsi Bali.

Tabel 6. Hasil Simulasi dengan Peningkatan Berat Berat Sapi, Penambahan Bibit dan Peningkatan Pemotongan pada Skenario 3

\begin{tabular}{lllllll}
\hline \multirow{2}{*}{ Tahun } & $\begin{array}{l}\text { Jumlah } \\
\text { Penduduk } \\
\text { Bali** }\end{array}$ & $\begin{array}{l}\text { Pemotongan } \\
\text { Sapi (ekor) }\end{array}$ & $\begin{array}{l}\text { Produksi } \\
\text { Daging Sapi } \\
\text { (Ton)** }\end{array}$ & $\begin{array}{l}\text { Kebutuhan } \\
\text { Daging } \\
\text { (Ton)** }\end{array}$ & $\begin{array}{l}\text { Ketersediaan } \\
\text { Saging } \\
\text { (Ton)** }\end{array}$ & Sapi \\
\hline 2012 & 4.007 .200 & $61.735,40$ & $29.624,8$ & $22.418,7$ & $7.206,1$ \\
2013 & 4.084 .520 & $52.701,00$ & $25.961,4$ & $22.438,0$ & $3.523,4$ \\
2014 & 4.162 .760 & $45.305,00$ & $23.396,9$ & $22.457,6$ & 939,3 \\
2015 & 4.241 .910 & $39.249,40$ & $21.601,9$ & $22.477,4$ & $-875,5$ \\
2016 & 4.321 .990 & $33.954,30$ & $20.251,5$ & $22.497,5$ & $-2.246,0$ & \\
2017 & 4.403 .020 & $29.342,80$ & $19.240,6$ & $22.517,8$ & $-3.277,2$ \\
2018 & 4.485 .010 & $25.341,34$ & $18.487,0$ & $22.538,3$ & $-4.051,3$ & \\
2019 & 4.567 .950 & $21.871,71$ & $17.924,7$ & $22.559,0$ & $-4.634,3$ \\
2020 & 4.651 .880 & $18.865,72$ & $17.505,0$ & $22.580,1$ & $-5.075,1$ \\
2021 & 4.736 .790 & $16.263,74$ & $17.191,6$ & $22.601,3$ & $-5.409,7$ & \\
\hline
\end{tabular}

Keterangan ** : nilai jumlah penduduk, produksi, kebutuhan dan ketersediaan daging sapi tiap tahun lebih tinggi dari hasil simulasi skenario 1.

\section{Alternatif Rekomendasi Kebijakan}

Alternatif rekomendasi kebijakan yang dapat disarankan pada ketersediaan daging sapi di Provinsi Bali yaitu dengan menaikkan bobot sapi dari $200 \mathrm{~kg}$ menjadi $300 \mathrm{~kg}$, penambahan bibit sapi sebanyak 40.000 ekor dan peningkatan pemotongan sapi dari $20 \%$ menjadi $30 \%$. Produksi daging sapi di Balihanya mampu memenuhi kebutuhan daging sapi sampai tahun 2015.Cara yang dilakukan untuk dapat memenuhi kebutuhan daging sapi adalah dengan cara program penggemukan sapi penambahan bibit sapi dan peningkatan pemotongan. Penggemukan sapi dapat dilakukan dengan cara memperhatikan pakan ternak yang akan diberikan. Pakan ternak yang baik dalam proses penggemukan adalah hijauan (hijauan unggul) dan pakan tambahan (konsentrat). Potensi daging sapi di Provinsi Bali menurut hasil simulasi masih mengalami kekurangan, maka dari ituimpor daging sapi masih perlu dilakukan untuk memenuhi kebutuhan daging sapi di Provinsi Bali.

\section{KESIMPULAN}

\section{Kesimpulan}

Berdasarkan penelitian yang telah dilakukan maka dapat disimpulkan beberapa hal sebagai berikut:

Faktor-faktor yang mempengaruhi ketersediaan daging sapi di Provinsi Bali yaitu populasi sapi betina, populasi sapi jantan, produksi daging sapi, impor daging sapi, pemotongan sapi jantan, pemotongan sapi betina, pertumbuhan penduduk, net migrasi, kebutuhan industri kornet dan sosis, kebutuhan industri bakso.

Model dinamis ketersediaan daging sapi yang telah disimulasikan dengan beberapa skenario mengalami peningkatan pada produksi daging sapi dengan upaya meningkatkan bobot berat sapi yang akan dipotong. Jika tidak terjadinya perubahan kebijakan maka kebutuhan dari awal simulasi tahun 2012-2021 tidak dapat terpenuhi.

Model yang dibuat merupakan replikasi dari sistem nyata yang memiliki dua submodel yaitu submodel produksi daging 
sapi dan submodel kebutuhan daging sapi.

Alternatif rekomendasi kebijakan untuk memenuhi kebutuhan daging sapi di Provinsi Bali yang diharapkan untuk diterapkandengan cara menaikkan bobot sapi yang akan dipotong, dari $200 \mathrm{~kg}$ menjadi 300 $\mathrm{kg}$, penambahan bibit sapi sebanyak 40.000 ekor dan peningkatan pemotongan dari $20 \%$ menjadi $30 \%$.

\section{Saran}

Potensi daging sapi lokal masih belum bisa mencukupi kebutuhan di Provinsi Bali, sehingga impor tidak bisa dihilangkan. Perlu diadakannya penelitian lebih lanjut dalam peningkatan produksi daging sapi dengan cara menerapakan program penggemukan sapi.

\section{DAFTAR PUSTAKA}

Badan Pusat Statistika Nasional. 2016. Produksi Daging Sapi Per Provinsi. https://www.bps.go.id/linkTableDinamis/ view/id/914. Diakses pada tanggal 26 April 2017.

Badan Pusat Statistik Provinsi Bengkulu. 2016. https://bengkulu.bps.go.id. Diakses pada 19 Januari 2017 pkl.13.30 Wita

Baskoro, A. W. 2009. Manajemen Penggemukan Sapi Potong di CV. Plesungan Raya Gondangrejo, Karanganyar. Skripsi. Fakultas Pertanian. Universitas Sebelas Maret. Surakarta.

Dinas Peternakan dan Kesehatan Hewan.2016. Cacah Jiwa Ternak di Provinsi Bali Tahun 2016.Dinas Peternakan dan Kesehatan Hewan. Provinsi Bali.

Ditjennak.2010. Pedoman Umum Program Swasembada Daging Sapi 2014. Direktorat Jendral Peternakan Kementrian Pertanian. Jakarta.

Forrester, J. W. 1994. "System Dynamics,
System Thinking, and Soft OR".System Dynamics Review Summer. New York. 10(2) : 1-14.

Garside, A. K. dan H. Y. Asjari. 2015. Simulasi Ketersediaan Beras di Jawa Timur. Jurnal Ilmiah Teknik Industri. 14(1):47-58.

Harmini, R. W. Asmrantaka, dan J. Atmakusuma. 2011. Model Dinamis Sistem Ketersediaan Daging Sapi Nasional. Jurnal Ekonomi Pembangunan. 12(1):128-146..

Hasan, N., E. Suryani, and R. Hendrawan. 2015. Analysis of Soybean Production and Demand to Develop Strategic Policy of Food Self Sufficiency: A System Dynamics Framework. Procedia Computer Science. 72:605-612.

Indayani, N. P., I. K. Satriawan, dan C. A. B. Sadyasmara. 2017. Sistem Dinamis Ketersediaan Buah Pisang di Provinsi Bali. Jurnal Rekayasa dan Manajemen Agroindustri. 5(2) : 77-87.

Kelton, W. D., R. P.Sadowski, and N. B. Swets, 2010.Simulation with Arena.McGraw Hill. New York.

Krisdayanti, N. K. L., I. K. Satriawan., dan I. W. G. S. Yoga., 2017. Sistem Dinamik Ketersediaan Kedelai dalam Rangka Swasembada Pangan di Provinsi Bali. Jurnal Rekayasa dan Manajemen Agroindustri. 5(3) : 45-56.

Taufik, M. N., C. Dewi, dan W. F. Mahmudy. 2017. Optimasi Komposisi Pakan untuk Penggemukan Sapi Potong Menggunakan Algoritma Genetika. Jurnal Pengembangan Teknologi Informasi dan Ilmu Komputer 1(7):571-582.

Udin, F., Marimin, Sukardi, A. Buono and H. Halid. 2014. A System Dynamics Simulation of Rice Agroindustry Development by Divestment Pattern for Increasing Rice Production and Farmer 
Income. Journal of Information Engineering and Applications. 4(12):8295. 